\title{
Albanian Public Policies, Financing Reforms and the Importance of Decentralization Process in Partnership with Foreign Direct Investments. Decentralization Process in Partnership with Foreign Direct Investments in Balcan Region.
}

PhD. Hava Mucollari

Accounting Ecpert, Tirana University Lector, Economy Faculty, Albania Email: hmucollari@yahoo.com

\author{
Prof. Assoc. Dr.Alba Robert Dumi
}

Dean of Graduated School, Ismail Qemali" Vlore University, Albania Economy Faculty, Management department, Vlora Albania

Email: besi.alba@yahoo.com

PhD. Zaim Korsi

Accounting Ecpert, Tirana University Lector, Economy Faculty, Albania Email: zaimkorsi@gmail.com

Ma. Elisabeta Duçellari

Accounting Ecpert, Tirana University Lector, Economy Faculty, Albania

Doi:10.5901/mjss.2013.v4n10p34

Abstract

This paper includes partnerships with community-based organizations, public and private colleges, universities, public school teachers, public health departments. Additionally, more number of community leaders have been trained to deliver educational workshops; PSI has developed a robust workshop leader database, which permits remote access to (and entry of) service delivery information. This will be an important point of administrative changes in Albanian public policies as an obstacle to the operating foreign investments, comparison of EU. Entrepreneurship ambition has worked to support changes in Albanian law that would offer anti-discrimination protections in keeping with international standards. Another point of administrative changes in Albanian public policies as an obstacle to the operating foreign investments, comparison of EU is: (1) International investments contributed to the improvement of Albania's financial regulatory environment which has strengthened public confidence in the banking system and has provided a more secure, efficient and transparent financial system to meet the credit, savings and insurance needs of businesses and individuals. The paper provides support for legislative initiatives and local government activities that advance the decentralization process and increase the control of local government by local constituents, thus decreasing the control of central authorities.

Keywords: Public policies, International standards, Local government activities, public goals.

\section{Introduction.}

The analyses of the major trading partners of the firms home country and those of the nations where it has affiliates that export can provide valuable insights to management.According to the definition of Martin Wolfe, Global Business analyst, Financial Times, October 1, 1997, pp.12 "Creating overseas production cities merely in order to meet local consumption looks an increasingly fragile basis for foreign investment. A much better one is the ability to make the best use of a companie competitive advantage by locating production wherever it is most efficient. 


\subsection{International trade and volume of the trade in economical view}

Today's multinationals create widespread network of research, component production assembly and distribution." We want together date from the development of foreign investments of Republic of Macedonia, Albania and Kosova. There are a number of advantages of in focusing attention on a national that is already sizable purchaser of goods coming from would - be exporter country. (Source: Departament of Commerce, Survey of current business, June, 1997, pp. 74)

\section{Literature Review and Hypotheses}

\subsection{Foreign direct investments, rapid increase in nowadays}

The financial system is undoubtedly the catalyst or to be more exact, the laboratory where economic developments take an appropriate form and shape. The role of the economy cannot be exaggerated and identified to the role of the financial system of a country, but at the same time, the very relevant role of the financial system in the development and prosperity of the national economy can neither be neglected nor be reduced. FDI has arisen rapidly from 185 billion $\$$ in 1985 to 360 billion \$ in 1996 (Source: World Investment Report, New York, 1997, pp.303). This is an average annual increase of nearly $12 \%$. Observe how concentrated FDI is in the United States. Nearly three-quarters of the total stock was owned by firms of just five nations: (1) United Kingdom (23 percent), (2) Japan (19 percent), (3) the Netherlands (12 percent), (4) Germany (9.9 percent), and (5) Canada (8.5 percent).

Why focus on major trading partners?

1. Business climate in importing nations is relatively favorable

2. Export and Import regulations are not insurmountable

3. There should be no strong cultural objections to buying that nations goods

4. Satisfactory transportation facilities have already been established.

On the record investment outlays in the U.S by foreign firms, much more has been spent to acquire going companies than to establish new ones. A number of reasons are responsible : (1) Corporate restructuring in this country caused managements to put on the market units that either did not meet management's profit standards or were considered to be unrelated to the company's main businesses, (2) foreign companies desired to gain rapid access in this country to advanced technology, especially in computers and communications, and (3) managements of foreign firms felt that entrance in to the large market and money promote foreign direct investments.(Source: International nature of business, July, 1999, pp.34).

\subsubsection{H 1: Are the direction and the priorities of financial system harmonized?}

In the post-communist period, expropriation has been limited to land needed for infrastructure projects, such as roads and airports. Compensation has generally been below market value and some owners have complained about the slow compensation process and low payments. The restitution process of properties confiscated during the communist regime started in 1993 but is still far from complete. The process is tainted with corruption and lack of political will. Several U.S. citizens and residents have long-running disputes with the government regarding restitution for property. Many property cases end up in the courts and drag on for years without a final decision. (Leung, Hok Lin 1998)

No requests will be accepted after the deadline. However the entire set of restitution compensation claims is not expected to be resolved before 2014. The GOA has presented three methods of compensation for expropriation claims: 1) restitution, 2) compensation of property with similarly valued land in a different location, and 3) cash settlement/financial compensation. The successful implementation of the restitution process is an important challenge for the government and is keys to future economic development.

\subsubsection{H 2: The direction and the priorities of the finanacial system are harmonized with the direction and development strategies of the Albanian economy?}

The property registration process has been completed in approximately $86 \%$ of the country and almost entirely in rural areas. However, more lucrative land in high value urban and coastal areas has still not been registered. Many of the unregistered properties are in the south coastal area, which is more valuable for its tourism potential, and where disputes are more frequent. 


\subsection{3 $\mathrm{H}$ 3: The main institutions dealing with property restitution and registration are the Agency for Restitution and Compensation and the Office for the Registration of Immovable Properties.}

This is a highly significant feature of infrastructure programs and carries important implications for local development.Sustained political pressure and the demonstrated capacity of municipalities to manage their responsibilities were the driving forces for local administrative and fiscal autonomy. Initial assessments suggested that decentralization did improve the quality of service delivery and foster a new, user oriented attitude, facilitating the transition from a centrally planned to a market economy. The low speed of the capital and rent circulation is another relevant feature of the empirical stage of the economic development. (Bundo, Luci, Cane 2002)

\subsubsection{H 4: Decisions on appeals are taken by the same unit of the PPA that is responsible for interpreting the law and giving advice to contracting authorities.}

\subsection{Banking activity and faciliting tranzition}

According to the recent Nobelists in the field of finance, an economy finds itself at the empirical stage of its development when the financial and banking sector is dominated by the cash economy. The second stage is the credit economy. During this stage, the role of the financial intermediation and credit institutions - mainly of banks - increases very much. The banking activity represents an important direction in terms of the transfer of resources and funds.

Current procedures for handling complaints still do not meet recognized international standards. Despite progress, its application is hampered by technical problems, the insufficient IT capacity of many contracting authorities and corruption in drafting tender documents. Companies continue to experience issues with transparency in specifications and communication in competing for public tenders. Overall, the improvements in the public procurement legislation are advancing while the proper enforcement of the law is still a work in progress.

\subsection{Research Goal and data collected}

The law "On Concessions," No. 9663, dated December 18, 2006, established the necessary framework for promoting and facilitating the implementation of privately financed concessionary projects enhancing transparency, fairness, efficiency and long-term sustainability in the development of infrastructure and public service projects. One of its major amendments includes a better regulation for unsolicited proposals and of public-private partnerships in general. The law applies to a wide range of sectors, including: Financing Reforms, Importance of Decentralization Processing Partnership, Foreign Direct Investments. The topic of the level of development of the financial system as well as its role in the acceleration of the economic development remains always present and open to discussions among the Albanian economic circles. Currently, our economy experiences a relatively high rate of economic growth. (Bodie Zvi (Nobelist),2001)

\subsection{Expropriation and Compensation of Foreign Direct Investment Statistics}

The FDI has increased although it still remains among the lowest in the region. The cumulative FDI is also the lowest in the region. The Bank of Albania reported the following figures for foreign direct investment in Albania. As a new market economy, it is passing from the phase of birth into the phase of growth. In addition to the characteristics and difficulties of the present phase, our economy carries as well development potentials having not been exploited yet. (Bundo, Luci, Cane 2000 int link)

Regardless of numerous contracts, only a few projects materialized in 2009. The entities that have surplus in resources and funds transfer them to the deficit entities. As a result, the level of economic development accelerates and alongside with that, the national wealth also increases. The third stage is that of the financial markets. (Leung, Hok Lin 1998)The financial intermediation institutions improve themselves to the extent that besides the liquidity intermediation institutions, the intermediation institutions for financial rights also develop. During the stage of the financial markets, the economy operates on the basis of the invisible money - the electronic money, whereas the titles and capitals are transferred and invested regardless of the national borders and without any quantitative or time limits 


\subsubsection{Fiscal and monetary policy and the financial markets}

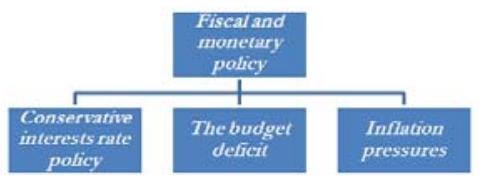

Figure 1. In 1996 and especially 1997 the economy lost its momentum, reflected also in the increase of CPI

The first stage is the empirical one. Undeveloped financial institutions as well as an undeveloped financial system characterize this stage. It belongs to the natural economy and to the low levels of economic growth and development. (Bundo, Luci, Cane 2000) In January 2000, the government promulgated a national Strategy for Decentralization and Local Autonomy which includes lows to strengthen the autonomy of local governments and increase their capacity to manage local infrastructure and services.

\begin{tabular}{|c|c|c|c|c|c|c|}
\hline Years & 2004 & 2005 & 2006 & 2007 & 2008 & $2009^{*}$ \\
\hline $\begin{array}{c}\text { FDI in million Euro in Balcan } \\
\text { counrties }\end{array}$ & 279 & 212 & 359 & 481 & 653 & 580 \\
\hline $\begin{array}{c}\text { Profitable in million Euro } \\
\text { Macedonia FDI }\end{array}$ & $32 \%$ & $28 \%$ & $32 \%$ & $35.8 \%$ & $41 \%$ & $52 \%$ \\
Kosovo FDI & 234 & 456 & 654 & 763 & 431 & 356 \\
Albania FDI & 112 & 102 & 345 & 342 & 338 & 224 \\
\hline
\end{tabular}

Source: Bank of Albania *A B estimate for the first three quarters of 2009

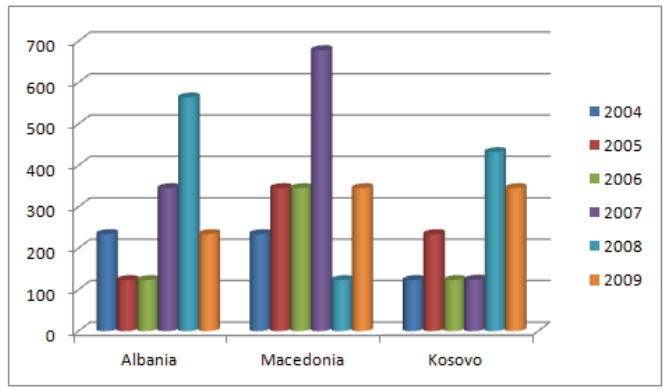

Source: Bank of Albania *A B estimate for the first three quarters of 2009

FDI during the first nine months of 2009 is estimated to have reached 580 million euro despite optimistic GOA projections for 2009 fueled mainly by strong investor interest witnessed during 2007-2008. A large part of FDI is due to privatizations. The Albanian government collected 103 million Euro from the privatization of 76 percent of the shares of the distribution arm of Albanian Power Corporation; 48 million Euro from the privatization of 12.6 percent of AMC state controlled shares; 5 million euro from the privatization of $40 \%$ of GOA controlled shares of the United Bank of Albania. INSIG (insurance company) privatization failed during the negotiation process with the winter and it might take place during 2010 . $\{1\}$ Albanian government report 2010 pg 12, 25,41,58,74

\section{Methodology and Research Goal}

Albania, one of the smallest and poorest countries in Eastern Europe, has experienced a transition marked by sharp economic swings and periods of civil strife. The early phases of decentralization witnessed the transfer of political autonomy and limited administrative and fiscal authority, to local governments, inadequate legislation outlining central/local responsibilities, scarce financial resources and deficient infrastructure strained the capacity of local governments to mange urban services. Bodie Zvi (Nobelist),2001) 
There exists an important postulate in the theory of finance on the role of the financial system: The level of development and the role of the financial system in the economy define the economic development stage of a country. Hence, based on the level, role and influence of the financial system on the economy, three stages can be identified with regard to the economic development. During the last decade the Albanian Public Administration is going under a reformation process, a process related with the political, economical and social changes.

At the beginning of the ' 90 the role of the Albanian state was modernized, and was stimulated to economic improvement and to conceal social injustice. (Robins P 2002). The new role of the state determined new obligations for the public, central and local administration. During this period the administration was nearly totally politicized and there were no clear divisions between the political and techno-professional functions. During this period the model of the political control was inappropriate and out of logic and it was still in the development phase.

During 1996-1999 the politicization of the administration ended and the administration was based on merits. The division between the political and techno-professional was clear. Several laws were approves; law no. 8095 in 21.03.96, "For the Civil Service in the Albanian Republic", The Decision of the Minister's Council no.657 in 16.09.96 "For ethic rules in the public service", law no. 8549 in 11.11.1999 "The status of the civil employee". All this laws were approved during this period. The administration had the possibility to implement a different system, in the human resources management in all the central and local institutions. (Dhima A 2003)

\subsection{The intermediation of banks, the financial system becomes more active.}

In the economy of the financial markets, the financial system shows the characteristics of infinite connections, transactions, relations and exchanges in financial flows and money, operations and national institutions, which form a chain of subsequent spiral and closed transactions.

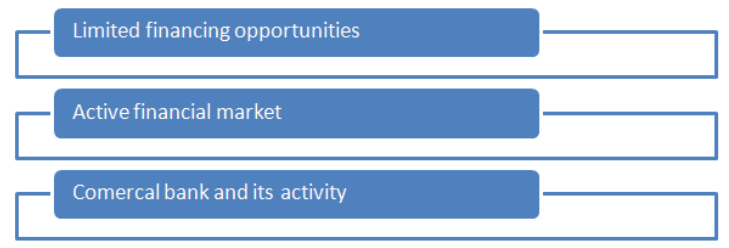

Source: Financial market and economic grouth, Bundo, Luci, Cane 2002)

Only when conceptualized as a whole thing, these elements give a meaning to the financial system. Hence, during these first 15 years of the market, the bank crediting and the financial market have offered limited financing opportunities for the economic growth. (Bundo, Luci, Cane 2000 int link)

The absence of an active financial market and the lack of transactions carried out through this market are facts not to be denied. Without referring to the statistics, these phenomena show that at present, the Albanian economy finds itself at the beginning of the second stage.

There are tens of enterprises that have been acquired, invested in or privatized, enterprises under a rapid growth process, with a multiplied market value, but because of the absence of their evaluation in the capital market, their market value remains unstated. At present, it is represented by a minimized amount registered in the accounting system of the enterprises and in the account of the owner, or at best, of a limited number of co-owners. (Leung, Hok Lin 1998)

It is entering the credit stage, a stage in which the role and activity of commercial banks is expected to increase further. The credit/deposit ratio, which ranges from 10 per cent in 2001 to 18.8 per cent in 2004, is the most significant indicator for this conclusion. At the same time, it can be concluded that the 283 role of the commercial credit - the credit that companies directly grant to each other - is limited. When we state that the Albanian economy is at the beginning of the second stage, this means that it tends to expand the activity and the role of banks, but not that the credit system and institutions have reached their maturity level.

\subsection{Analyzing data and questionaries}

It can certainly be said that the priority sectors of the economy have been clearly defined in the economic development strategies of our country, be them sectoral or of a general character, as for instance the strategy on the economic 
development and poverty reduction. As a result, besides the support of the state for education, health care and social protection, sectors such as agriculture, food industry, tourism and construction are visibly considered as the priority sectors of our economy. This priority is based on many essential factors such as natural resources and geographic position, the cultural patrimony and tradition, human resources and strategic position. A major part of these strategies have been approved in scientific forums, including the Albanian government. (Bodie Zvi (Nobelist ,2001)

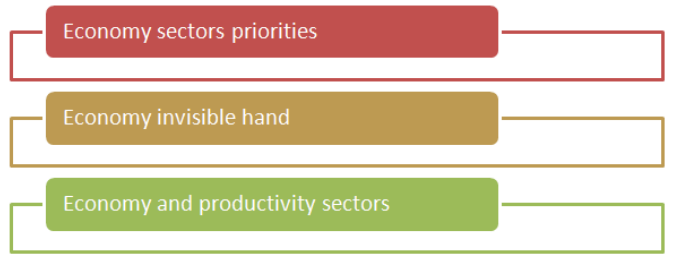

Source: Financial market and economic grouth (Bannet and Shultter 2012)

It means that our economy and our state have defined the path of development 292 priorities. It also means that these sectors, defined as priority ones, will be as a focus of the controlled developments and orientation and promotion policies. (Goffin Robert 2001)

Meanwhile, it remains relevant to discuss whether the Albanian financial system has the same priorities or not. Are the directions of the priorities of the economic sectors harmonized with the directions of the financial system? If the answer were yes, this would be evidence to a development and progress in the right direction. If not, we need to make the necessary adjustments. This is an important issue. (Guxholli $Z$ 2011)

The great discoveries in finance and the increase of its role are in conflict with the great concentration of authority on the central levels. This economic equation cannot be solved by an invisible hand or by the state control. We have the impression that both the financial system in general and the banking system in particular have maintained a certain distance from agriculture.

Our financial system still is unable to find its attractive force in the agriculture and the agricultural and animal products.Meanwhile, the misuse of the agricultural land and its occupation by various constructions is becoming a very worrying phenomenon. Many activities in Albania required cumbersome licensing procedures and permits. In 2007, the GOA approved the Action Plan for Regulatory Reform which provided for a full review of Albania's entire legal licensing system to harmonize the licensing legislation to EU standards and reduce administrative barriers for businesses operating in Albania. (Guxholli Z, 2011)As a result, many licenses were removed while a broad simplification of licensing procedures has been completed in many sectors including, mining, hydrocarbons, public works, health, agriculture and the environment.

By October 2008, 64 out of 151 licenses identified in 18 sectors of the economy were removed and another 21 licenses were changed into self-declaration. The protection and the proper use of limited agricultural land, as well as the indifference of the financial mechanisms in encouraging and promoting its use and exploitation, represent a visible deficiency in the harmonization of the direction of production strategies and economy branches with the direction of the financial system. The main issues handled out in this presentation are: strengthening local government leadership and initiative; partnership between municipalities and NGOs; concluding all of these in the community-based approaches to infrastructure services and neighbourhood revitalization.

\subsection{Sample and Data Collection}

Almost everywhere problems of water scarcity can be considerably mitigated through metering, leakage detection and reduction, network improvements, disconnection of illegal connections, and optimization of storage and supply patterns. The distribution problem in Albania also has a seasonal aspect: much more water is needed during the summer growing season; when rainfall is scarce, rural drinking water is often misused for irrigation; and the tourist resort areas use large amounts of water. (Bodie Zvi (Nobelist),2001)

Decentralization has given local governments the discretion and scope they need to take a lead role in responding to the challenges of economic down-turn, degradation of the urban environment, and social hardship. They institute bold initiatives and innovative practices. Western European nations have put in place sophisticated frameworks to provide 
local governments with technical and financial assistance. The European Union supplements these national programs with coordinated assistance aimed at promoting economic development, assisting distressed localities and fostering social inclusion.

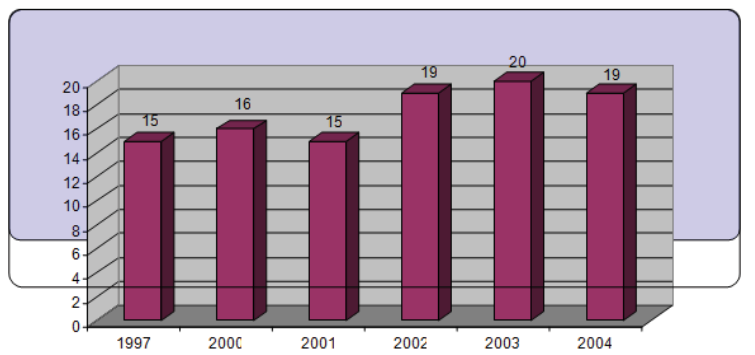

Tab 1. Albanian Municipal Water and Sanitation Project - Agricultural ministry project 2004

Work is in progress to identify other licenses that could be removed. For the remaining licenses the government plans to start a "One-Stop-Shop" for licensing within the first quarter of 2009. However, licensing and post-registration processes require further simplification and the removal of licenses needs to be accompanied by a strengthening of the supervision capacities of public agencies. The procedures for getting a license are the same for national and foreign companies. (Goffin Robert 2001)

\section{Infrastructure is an important component of these programs.}

Despite its location in an industrialized province Jerez's economy relies on wine production which, in recent years has been declining. Weak community participation, inadequate infrastructure, poor accessibility to regional resources and an unskilled labor force compounded the effects of massive job cuts in the wine industry.Meanwhile, the role of the financial market remains limited to only some money market operations. The capital market is de facto inexistent. As a result, the rapid growth of the value of the particular assets market or of the enterprises market, during the last 10-15 years, is still an unexploited source, which is practically impossible to be included in the acceleration of the country's economic circulation. (Goffin Robert 2001)

\section{Conclusions and Recommendations}

The Public Procurement Advocate was established as an independent institution reporting to parliament. However, it has no particular executive powers and its functions duplicate the monitoring tasks of the PPA (C. S George) Decisions on appeals are taken by the same unit of the PPA that is responsible for interpreting the law and giving advice to contracting authorities. Current procedures for handling complaints still do not meet recognized international standards. Overall, the improvements in the public procurement legislation are advancing while the proper enforcement of the law is still a work in progress. (Hardt 2009; Rieker 2009)Most banks today offer unsecured lines of credit targeted to small business owners.

If yours is an established company, you may be able to apply for a credit line amount of between $\$ 10,000$ and $\$ 50,000$ by completing a simple one-page application, with no business financial statements or tax returns required. Institutionally, the successful implementation of the Northern Dimension Countries relies on using flexible coordination mechanisms. Within the EU, the Northern Dimension is part of the Union's external relations but cuts across all its three pillars: the funding instruments stem from the first pillar of the single market, the objectives come at least partly from the second pillar of external relations and some of the problems relate to the third pillar of justice and home affairs, including management of border regimes. (C. S George)

\section{References}

Overseas Private Investment Corporation, 1100 New York Ave., NW Washington, the assessmentof the affects of certain public and private projects on the environment", pg 123-129 
Official Journal of the European Communities, L175, pages 40-48 "

Towards sustainability-a European Community programme of policy and actions in relation to the environment and sustainable development" 23 final- vol 11 (Commission of the European Communities), 1992.

Leung, Hok Lin. Land Use Planning Made Plain Ronald Fruye

Bradler\& Sediss The raport Company: Kingston, Ontario, 1989.

Hydric Management Departament of the Environment public administration, London 1996.

Albania: Municipal Water and Sanitation Project - Social Assessment.

Albanian Agricultural ministry report 2009 pg 14-18, Health Care Institute, Albania "Fokus article " pg 6-7

Albanian government report $2010 \mathrm{pg}$ 12, 25,41,58,74 Govern of Albania project $2009 \mathrm{pg} 14$

Bodie Zvi (Nobelist), Merton Robert, Finance, (2002), foreword from

Paul Samuelson, Nobelist.

Goffin Robert, Principes de Finance Moderne, 3e édition, (2001).Rules and Regulations of Bank of Albania, 1st volume.

Bundo Sherif, Savings and financial and banking system in the Albanian economy, from the book: The economic and social developments of the Albanian regions and their regional and world integration, (2000).

Bundo Sherif, Luçi Edlira, On a range of policies that encourage the domestic production, from the book: The domestic production - the energy of progress, (2002)

Bank of Albania, Annual Report, 2003 